\title{
The Release of Elements from Dental Casting Alloy into Cell-Culture Medium and Artificial Saliva
}

Gülșen Cana, Gül Akpınarb, Ahmet Aydın

\section{ABSTRACT}

Objectives: The biocompatibility of dental casting alloys is a critical issue because these alloys are in long-term intimate contact with oral tissues. Since the biocompatibility of alloys is not completely known; the release of elements from the alloys has been studied. The aim of this study was to compare the elemental release from dental casting alloy during exposure to artificial saliva and cell-culture medium.

Materials and Methods: Twenty specimens made from Ni-Cr alloy were provided in the form of $5 \mathrm{~mm}$ diameter discs, $2 \mathrm{~mm}$ in thickness with a $7 \mathrm{~mm}$ stem attached to one face to facilitate handling. Ten of twenty samples were polished separately using a conventional technique. The remaining ten samples were left sandblasted with $50 \mu \mathrm{m} \mathrm{Al} \mathrm{O}_{3}$. Ten samples ( 5 polished, 5 sandblasted) were separately placed into cell-culture wells with Dulbecco's Modified Eagle's Medium. The other ten samples were placed separately into cell-culture wells with artificial saliva. The samples were subjected in contact with these medium for 30 days. These medium were collected every 7 days. The cell-culture medium and artificial saliva without alloy samples were subjected to elemental analyses as a control. At the end of the exposure time, Atomic Absorption Spectrometry (AAS) was used to determine the release of elements from the alloys into all collected medium. Statistical analyses were assessed with two-way ANOVA.

Results: In general, the elemental release occurred with in all medium. The elemental releases of sandblasted alloys were higher than polished alloys. Artificial saliva was found to cause more release from the samples. In both media, Ni released from polished and sandblasted alloys were higher than $\mathrm{Cr}$ and Mo.

Conlusions: The results suggest that the release of elements from the alloys might have correlated with the environments and the surface of dental alloy. (Eur J Dent 2007;2:86-90)

Key Words: Dental alloy; Ni-Cr alloy; Elemental release; Biocompatibility; Cell-culture medium; Artificial saliva.

\section{INTRODUCTION}

Dental casting alloys with high and low noble metal contents are widely used in dentistry.

\footnotetext{
$\square$ a Department of Prosthodontics, Faculty of Dentistry, University of Ankara.

b SSYB Osmanlı Dental Treatment and Prosthetic Department.

Department of Pharmaceutical Toxicology Gülhane Military Medical Academy.

$\square$ Corresponding author: Prof. Dr. Gülșen CAN Ankara Üniversitesi Diș Hekimliḡi Fakültesi Protetik Diș Tedavisi Anabilim Dalı 06500 Besevler, Ankara, Turkey. Tel: +90 3122965698 Fax: +90 3122123954 E-mail: candadentistry.ankara.edu.tr
}

Corrosion of alloys occurs in oral environment. The biocompatibility of dental casting alloys is a critical issue because these alloys are in longterm intimate contact with oral tissues. The biocompatibility may correlate with elements of dental casting alloys. ${ }^{1-3}$ The release of elements from dental casting alloys is directly related to adverse biological effects. Certain environmental conditions around the alloy will affect the release of elements. A reduction in $\mathrm{pH}$ will increase elemental release from dental alloys. This effect is especially pronounced for nickel-based alloys. The elemen- 
tal release from casting alloys has also been studied extensively in vitro in short and long term experiments. ${ }^{4-8}$

Studies have shown that the release of elements from the alloys may correlate with different factors. Wataha and other many investigaters ${ }^{2-4,7-9}$ have been studied about the affects of the ions released. They have shown that the relationships between elemental release and toxicity are complex. Several statements can be said about release of elements from dental alloys. In the mouth, alloys may be exposed to transient $\mathrm{pH}$ changes either from foods or plaque. The reduced $\mathrm{pH}$ would increase elemental release because it acts like corrosive medium.

The purpose of this study was to compare the elemental release from polished and sandblasted dental casting alloy during its exposure to artificial saliva and cell-culture medium.

\section{MATERIALS AND METHODS}

\section{Sample preparation}

Twenty specimens made from nickel-chromium (Ni-Cr) alloy (Cr 22.5, Ni 65, Mo 9.5, Fe 0.5, Si 1.0, C 0.02, Ce 0.5, Nb 1.0, weight \%) (Wiron 99 , Bego, Germanyl were provided in the form of 5 $\mathrm{mm}$ diameter discs, $2 \mathrm{~mm}$ in thickness with a 7 $\mathrm{mm}$ stem attached to one face to facilitate handling, similar to the study of Wataha and Lockwood. ${ }^{9}$

Ten of twenty samples were polished separately using a conventional technique. The remaining ten samples were left sandblasted with $50 \mu \mathrm{m} \mathrm{Al} \mathrm{O}_{3}$. Each sample was then cleaned by a soft toothbrush, rinsed in distilled water, and ultrasonically treated in $99 \%$ ethanol for $15 \mathrm{~min}$.

After cleaning, 10 samples ( 5 polished, 5 sandblasted) were separately placed into cell-culture well. Then the cell-culture medium was added in this well $10.5 \mathrm{ml}$ Dulbecco's Modified Eagle's Medium-Ham's F-12, pH 7.4, Sigma, USAl that containing penicillin (100 units/mL), streptomycin (100 mikrog/mL), amphotericin B (2,5 mikrog/mL) and sodium bicarbonate $(1.2 \mathrm{~g} / \mathrm{L})$ in a $37^{\circ} \mathrm{C}$, humidified $5 \% \mathrm{CO}_{2}$ atmosphere. The other ten samples were placed separately into cell culture wells; then $0.5 \mathrm{ml}$ artificial saliva $(0.017 \mathrm{~mol} \mathrm{NaCl}, 0.02 \mathrm{~mol}$ $\mathrm{Na}_{2} \mathrm{HPO}_{4}, 0.02 \mathrm{~mol} \mathrm{NaH} \mathrm{PO}_{4}, \mathrm{pH} 3.5,37^{\circ} \mathrm{C}$ ) was added. ${ }^{10}$

The samples were subjected in contact with this medium for 30 days. The cell-culture medium and artificial saliva without alloy samples were analyzed to elemental analyses as a control for the presence of metal elements. The cell-culture and artificial saliva were collected aseptically every 7 days and new medium were placed in the cell-culture wells.

\section{Atomic absorption spectrometry analysis}

Atomic absorption spectrometry analysis (AAS) (Varian 30/40 Model, GTA 96, Australia) was used to determine the release of elements from the alloys into collected the cell-culture medium and artificial saliva solutions. Nickel (Ni), Chromium (Cr), and Molybdenum (Mo) elements were selected for analysis based on previous research which showed that they were released from dental casting alloy. The other elements in the $\mathrm{Ni}-\mathrm{Cr}$ alloys were not checked because they are trace elements in the compositions. In the AAS, there are certain measurement ranges each element. For this reason, standard solutions were used for calibration of each element. Standard solutions were prepared by dilution of purchased 1000 ppm stock solutions with double-distilled water. To check the accuracy of the standards, the calibration graphics were obtained for each element. The specific parameters (wavelength, slit width, standard concentration) used for detection of each element for AAS technique, are listed in Table 1.

Statistical analyses were assessed with twoway ANOVA. At the same time, Kolmogorow-Simirnow and repeated measures of ANOVA were used.

\section{RESULTS}

The release amount of elements in both artificial saliva and cell-culture medium were deter-

Table 1. Atomic absorption spectrometry parameters.

\begin{tabular}{cccccc}
\hline & $\begin{array}{c}\text { Wavelength } \\
(\mathrm{nm})\end{array}$ & $\begin{array}{c}\text { Slit width } \\
(\mathrm{mA})\end{array}$ & \multicolumn{3}{c}{$\begin{array}{c}\text { Standart } \\
\text { concentration }(\mathrm{ng} / \mathrm{ml})\end{array}$} \\
\hline $\mathrm{Ni}$ & 232 & 4 & 20 & 40 & 60 \\
$\mathrm{Cr}$ & 357.9 & 7 & 5 & 10 & 5 \\
$\mathrm{Mo}$ & 313.9 & 7 & 10 & 20 & 30 \\
\hline
\end{tabular}


mined to $\mathrm{ng} / \mathrm{ml}=$ mikrogram/L=ppm. These data were obtained like this: (the experimental resultthe control result). The results are illustrated in Tables 2,3 and Figure 1.

Medium, polished and sandblasted alloys and interaction between them were analyzed. Although each elements show different release, it was clear from the data that extraction solution and the surface altered the release of elements.

In every medium, the effects of polished and sandblasted alloys were different. In cell-culture medium, the release of sandblasted alloy was more than polished alloy for $\mathrm{Ni}$ and Mo. The amount of released $\mathrm{Cr}$ was very low. In artificial saliva, the pattern of release was same with the other medium, but the amount of release was more than cell-culture medium. The release of $\mathrm{Ni}$ was statistically significant $(\mathrm{P}<.001)$ according to medium, sandblasted and polished alloys and the interaction of medium and surfaces in every medium. The release of Mo was not statistically significant for every medium (P>.05). At the other hand it was statistically important for surface $(P<.01)$ and interaction between medium and surface $(P>$.05). The release of $\mathrm{Cr}$ was very low. Its correlation with medium, surface and interaction between them was less important $(P<.001)$.

\section{DISCUSSION}

Dental alloys are subjected to a variety of chemical environment in the mouth. The dynamic natures of intraoral conditions cause corrosion. The release of an element from alloy depends on some factors such as the nature of element, alloy composition, multiple phases of alloy the metallurgical environment around these alloy and polished alloy. Therefore some of metal elements have an inherently higher tendency to be released from dental alloys. The biological liabilities may be related to the released elements.

Many studies have been performed about the release of metallic elements from dental alloys. The release of elements from dental casting alloys has been investigated with many different material and methods by different researchers. ${ }^{2-4,6-9,11}$

Certain environmental conditions around the alloy affect release of elements. Cell culture or different solution such as normal saline, bovine serum solution, artificial saliva, tissue culture media and diluted acids are used to evaluate the corrosion. ${ }^{2,4,6-11}$

A reduction in $\mathrm{pH}$ increases elemental release from dental alloys. This effect is especially pronounced for Ni-based alloys.,11-14 Although, for the Ni-based alloy, $\mathrm{pH}$ appeared to be the dominating factor and the composition of the solution is less important. Liability of $\mathrm{Ni}$ element from $\mathrm{Ni}$ based alloys in acidified saliva was confirmed by Covington. ${ }^{11}$ He showed that; especially Ni tends to be released from these types of alloys in acidified saliva. Wataha et al, $^{12}$ in a various solution with $\mathrm{pH}$

Table 2. Elemental release from dental casting alloy in cell culture medium. Values are mean \pm sd.

* $P<.01$ when compared with sandblasted.

\begin{tabular}{ccc}
\hline & Polished & Sandblasted \\
\hline $\mathrm{Ni}$ & $425.66 \pm 119.89$ & $566.06 \pm 136.41$ \\
$\mathrm{Cr}$ & $1.45 \pm 1.15$ & $0.57 \pm 0.16$ \\
$\mathrm{Mo}$ & $33.27 \pm 20.33^{*}$ & $104.42 \pm 24.22$ \\
\hline
\end{tabular}

Table 3. Elemental release from dental casting alloy in artificial saliva. Values are mean \pm sd. * $P<.05$ when compared with sandblasted.

\begin{tabular}{lcc}
\hline & Polished & Sandblasted \\
\hline $\mathrm{Ni}$ & $768.75 \pm 228.91^{*}$ & $1539.0 \pm 543.93$ \\
$\mathrm{Cr}$ & $33.95 \pm 30.41$ & $2.72 \pm 3.15$ \\
$\mathrm{Mo}$ & $105.94 \pm 67.82$ & $115.66 \pm 62.30$ \\
\hline
\end{tabular}

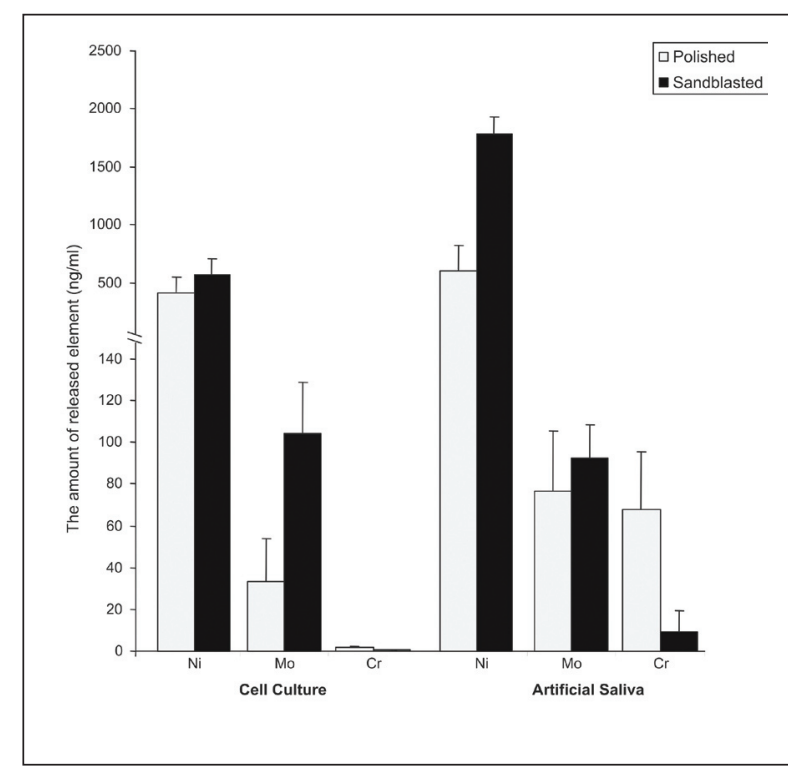

Figure 1. The release amount of $\mathrm{Ni}, \mathrm{Cr}, \mathrm{Mo}$ from polished and sandblasted $\mathrm{Ni}-\mathrm{Cr}$ alloy in cell culture medium and artificial saliva. 
ranging between 1-7 simulating intraoral dynamic conditions, investigated the release of elements from Ni-based alloys in 30 minutes. The authors found that the elemental release was increased in $\mathrm{pH}$ 1-4. Wataha9 measured the release of elements from dental alloys at monthly intervals for 10 months. They hypothesized that element release should decrease as a function of time of exposure to the medium and that the cytotoxic effects of the alloys should also decrease. Also, they stated that the initial release rates were the highest. ${ }^{13}$

Our results revealed that $\mathrm{Ni}$ was more active than $\mathrm{Cr}$ and $\mathrm{Mo}$ in both mediums and polished and sandblasted alloys. As expected, reduced $\mathrm{pH}$ dramatically increased $\mathrm{Ni}$ release from the $\mathrm{Ni}$-based alloy in the present study. This result is essentially identical to trends seen in previous studies performed in a 72 hours period. The release of elements in a cell-culture medium, were generally less than those in artificial saliva. ${ }^{14,15}$

Previous studies support the idea that composition of the alloy surface is critical to elemental release behavior for base-metal alloys.5,8,16 The elemental release may be caused by a change in surface composition of the alloys. This type of change was observed in $\mathrm{Pd}-\mathrm{Cu}$ alloys. Cu released initially leaving of the alloy before $\mathrm{Pd}$.

The results of our study showed that the release of $\mathrm{Ni}$ from sandblasted $\mathrm{Ni}-\mathrm{Cr}$ dental alloy was identical to the previously reported observations. ${ }^{14,15}$ The release of Mo was less than that of $\mathrm{Ni}$ because it is not an active metal. We expected that release of $\mathrm{Cr}$ would be minimal since chromium oxide layer formed prevents corrosion. In fact, our findings confirmed this assumption.

Nelson et al $^{17}$ evaluated the elemental release and cytotoxicity of casting alloys in three types solutions. They stated that cell-culture medium was much more complex than biological medium. However, in our study the elemental release from dental casting alloy into the cell-culture medium was not affected as much as in artificial saliva. Our hypothesis was supported by the other studies. ${ }^{18,20}$ When the cell-culture medium was compared to the artificial saliva, the data showed clearly that the release of $\mathrm{Ni}, \mathrm{Cr}$ and $\mathrm{Mo}$ were lower in cellculture medium.

Messer and Lucas ${ }^{19}$ showed that a number cellular functions were altered in response to ions released from $\mathrm{Ni}-\mathrm{Cr}$ alloys. Their results demon- strated ionic release from alloy was a complex process depended on variables including ion chemistry, ion valence and dose-time dependence.

\section{CONCLUSIONS}

The cytotoxicity of the alloys is complex and remains incompletely understood. The biocompatibility of dental materials is a critical concern with the development of new product.

\section{ACKNOWLEDGEMENTS}

This study was supported by a grant in Aid to Scientific Research (No:97-0200009) from Ankara University, Ankara, Turey. It was also financially supported by projects DPT 98K120730 and TUBITAK to $G C$ and $G A$.

\section{REFERENCES}

1. Can G, Akpınar G, Can A. Effects of base-metal castings alloy cytoskeletal filaments in cultured human fibroblasts. Int J Prosthodont 2004;17:45-51.

2. Wataha JC, Malcolm CT, Hanks CT. Correlation between cytotoxicity and the element release by dental casting alloys. Int J Prosthodont 1995;8:9-14.

3. Wataha JC. Biocompatibility of dental casting alloy: a review. J Prosthet Dent 2000;83:223-234.

4. Brune D. Metal release from dental biomaterials. Biomaterials 1986;7:163-175.

5. Bumgardner JD, Lucas LC. Surface analysis of nickelchromium dental alloys. Dent Mater 1993;9:252-259.

6. Geis-Gerstorfer JG, Sauer KH, Passler K. Ion release for $\mathrm{Ni}-\mathrm{Cr}-\mathrm{Mo}$ and $\mathrm{Co}-\mathrm{Cr}-\mathrm{Mo}$ casting alloys. Int $J$ Prosthodont 1991;4:152-158.

7. Tai Y, De Long R, Goodkind RJ, Douglas WH. Leaching of nickel, chromium and beryllium ions from base metal alloy in an artificial oral environment. J Prosthet Dent 1992;68:692-697.

8. Wataha JC, Malcolm CT. Effect of alloy surface composition on release of elements from dental casting alloys. $J$ Oral Rehabil 1996;23:583-589.

9. Wataha JC, Lockwood PE. Release of elements from dental casting alloys into cell- culture medium over 10 months. Dent Mater 1998;14:158-163.

10. Mallakh BF, Sarkar NK. Fluoride release from glass ionomer cements in the de-ionize water and artificial saliva. Dent Mater 1960;6:118-122.

11. Covington JS, Me Bridge MA, Slagle WF, Disney AL. Quantifications of nickel and beryllium leakage from base metal casting alloys. J Prosthet Dent 1985;54:127-136.

12. Wataha JC, Lockwood PE, Khajotia SS, Turner R. Effect of 
$\mathrm{pH}$ on element release from dental casting alloys. J Prosthet Dent 1998;8:691-698.

13. Wataha JC, Lockwood PE, Nelson SK. Initial versus subsequent release of elements from dental casting alloys. $J$ Oral Rehabil 1999;26:798-803.

14. Wataha JC, Craig RG, Hanks CT. The release of elements of dental casting alloys into cell-culture medium. Dent Res 1991;70:1014-1018.

15. Johansson BI, Lemons JE, Hao SQ. Corrosion of dental copper, nickel and gold alloys in artificial saliva and saline solutions. Dent Mater 1989;5:324-328.

16. Wataha JC, Lockwood PE, Noda M, Nelson SK, Mettenburg DJ. Effect of tooth brushing on the toxicity of casting alloys. J Prosthet Dent 2002;87:94-98.

17. Nelson SK, Wataha JC, Neme AML, Cibirka RM, Lockwood PE. Cytotoxicity of dental casting alloys pretreated with biologic solutions. J Prosthet Dent 1999;8:591-596.

18. Al- Hiyasat AS, Darmani H, Bashabsheh OM. Cytotoxicity of dental casting alloys after conditioning in distilled water. Int J Prosthodont 2003;16:597-601.

19. Messer RLW, Lucas LC. Cytotoxicity of nickel-chromium alloys: bulk alloys compared to multiple ion salt solutions. Dent Mater 2000;16:207-212.

20. Wataha JC, Nelson SK, Lockwood PE. Elemental release from dental casting alloys into biological media with and without protein. Dent Mater 2001;17:409-414. 